hyperaldosteronism caused by a renin dependent hy pertensive state, appropriate treatment would be very different, with the need to consider spironolactone or triamterine (as might have been helpful in our patient), before the diagnosis is established.

This work was supported in part by a grant from the Kidney Research Aid Fund. We are grateful to Dr P Sever, St Mary's Hospital, London, for measurement of plasma noradrenaline.

\section{References}

1 Liddle GW, Bledsoe T, Coppage WS. A familial renal disorder simulating primary aldosteronism but with negligible aldosterone secretion. In: Baulieu EE, Robel P, eds. Aldosterone. Oxford: Blackwell Scientific, 1964: 353-68.

2 Gardner JD, Lapey A, Simopoulos AP, Bravo EL. Abnormal membrane sodium transport in Liddle's syndrome. J Clin Invest $1971 ; 50: 2253-8$.

3 New MI, Levine LS, Biglieri EG, Pareira J, Ulick S.
Evidence for an unidentified steroid in a child with apparent mineralocorticoid hypertension. $J$ Clin Endocrinol Metab 1977;44:924-33.

4 Shackleton CHL, Honour JW, Dillon MJ, Chantler C, Jones RWA. Hypertension in a four year old child: gas chromatographic and mass spectrometric evidence for deficient hepatic metabolism of cortisol. J Clin Endocrinol Metab 1980;50:786-92.

5 Fiselier TJW, Otten BJ, Monnens LAH, Honour JW, Van Munster PJJ. Low renin, low-aldosterone hypertension and abnormal cortisol metabolism in a 19 month old child. Horm Res 1982;16:107-14.

6 Oberfield SF, Levine LS, Carey RM, Greig F, Ulick S, New MI. Metabolism and blood pressure responses to hydrocortisone in the syndrome of apparent mineralocorticoid excess. J Clin Endocrinol Metab 1983;56:332-9.

Correspondence to Dr J W Honour, Cobbold Laboratories, Thorn Institute of Clinical Science, The Middlesex Hospital Medical School, London WIN 8AA.

Received 25 July 1983

\title{
Early treatment of familial hypophosphataemic rickets
}

\author{
M ROZA, M A MIGUEL, M GALBE, L MEJIDO, AND C MENCIA \\ Department of Paediatrics, Hospital General de Asturias, Oviedo, Spain
}

SUMMARY A $2 \frac{1}{2}$ year old girl in whom familial hypophosphataemic rickets was diagnosed at age 2 months, has been treated since then with oral $1 \alpha, 25$-dihydroxycholecalciferol and phosphate. She has not, so far, developed osseous lesions.

Recent research into the metabolism of vitamin D has led to knowledge of its active forms and treatment applications. Despite its successful therapeutic effects in hypophosphataemic rickets (HR), opening a new field in the physiopathological research into this disease, not all the mechanisms are known. We present a patient in whom the early treatment of familial HR with 1 $\alpha, 25$-dihydroxycholecalciferol $\left(1 \propto, 25\left(\mathrm{OH}_{2}\right)_{3}\right)$ and phosphate (Joulie's solution) prevented the onset of bone lesions.

\section{Case report}

A girl, aged $2 \frac{1}{2}$ years at the time of this report, had been observed since birth. Her mother was known to have a sporadic form of HR with severe bone abnormalities (osteomalacia) and dwarfism, and had been treated during infancy with combined phosphates and vitamin $\mathrm{D}_{3}$ without any improvement. The pregnancy was normal, and a caesarean section was performed for maternal indications.
Our patient's birthweight was $3.3 \mathrm{~kg}$ and her length was $52 \mathrm{~cm}$.

A physical examination at age 2 months showed her to be normal-weight and height at the 25 th centile. Laboratory investigations at that time found the following: hypophosphataemia-phosphate 113 $\mathrm{mmol} / \mathrm{l}(3 \cdot 5 \mathrm{mg} / \mathrm{dl})$, normal range for our laboratory $1 \cdot 29-2 \cdot 09 \mathrm{mmol} / \mathrm{l}$; normal serum calcium-2.3 $\mathrm{mmol} / \mathrm{l}(9 \cdot 2 \mathrm{mg} / \mathrm{dl})$, normal range $2 \cdot 1-2 \cdot 6 \mathrm{mmol} / \mathrm{l}$; raised alkaline phosphatase - $56 \mathrm{KA}$ units, normal range $7 \cdot 5-32.5 \mathrm{KA}$ units; hypocalciuria-0.0365 $\mathrm{mmol} / \mathrm{kg} / 24$ hours $(1.46 \mathrm{mg} / \mathrm{kg} / 24$ hours $)$; hyperphosphaturia- $45.54 \mathrm{mmol} / 1 \cdot 73 \mathrm{~m}^{2} / 24$ hours $(1.41$ $\mathrm{mg} / 1 \cdot 73 \mathrm{~m}^{2} / 24$ hours); and a reduction in renal tubular reabsorption of phosphate $-60 \%$.

Renal function parameters were normal: glomerular filtration rate (GFR) estimated by creatinine clearance was $70 \mathrm{ml} / 1 \cdot 73 \mathrm{~m}^{2} /$ minute, with GFR of sodium, calcium, and potassium 0.09 $\mathrm{ml} / 100 \mathrm{ml}, 0.17 \mathrm{ml} / 100 \mathrm{ml}$, and $6.98 \mathrm{ml} / 100 \mathrm{ml}$ of filtrate. Aminoaciduria was normal, urine density was 1028; and $\mathrm{pH}$ 5. Plasma bicarbonate was $23 \cdot 8$ (mEq) $\mathrm{mmol} / \mathrm{l}$ and plasma $\mathrm{pH}$ was $7 \cdot 38$. After intravenous loading of phosphate there was an important reduction in the maximal tubular excretory capacity of phosphate (GFR $3.6 \mathrm{mg}(1.2 \mathrm{mmol}) /$ $100 \mathrm{ml}$ filtrate). Knee and wrist radiographs were normal. 
(a)

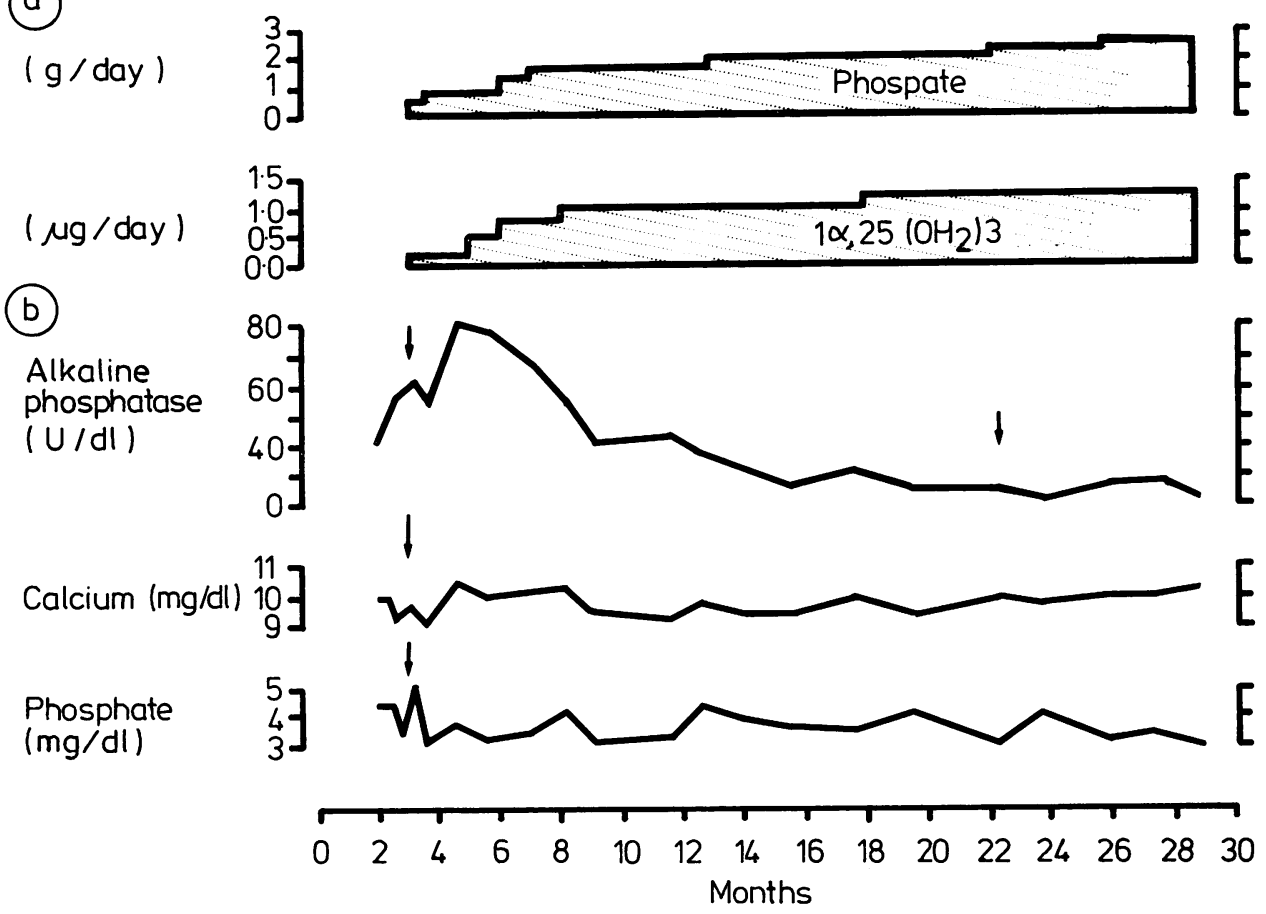

Figure Treatment (a) and laboratory investigations $(b)$ over a period of 28 months in a child with familial hypophosphataemic rickets.

Conversion: traditional units to $\mathrm{SI}-$ calcium $1 \mathrm{mg} / \mathrm{dl} \approx 0.25 \mathrm{mmol} / \mathrm{l}$; phosphate $1 \mathrm{mg} / \mathrm{dl} \approx 0.323 \mathrm{mmol} / \mathrm{l}$.

Treatment with oral phosphate was started at ar dosage of $600 \mathrm{mg} /$ day (in 6 divided doses) and $1 \alpha, 25\left(\mathrm{OH}_{2}\right)_{3}$ at a dosage of $0 \cdot 25 \mu \mathrm{g} /$ day. These doses were increased until the alkaline phosphatase value was normal-at $2 \cdot 2 \mathrm{~g}$ /day phosphate and $1 \cdot 25 \mu \mathrm{g} /$ day $1 \alpha, 25\left(\mathrm{OH}_{2}\right)_{3}$. Plasma phosphate was always above $1.066 \mathrm{mml} / 1(3 \mu \mathrm{g} / \mathrm{dl})$ and no hypercalcaemic episodes were detected (Figure). At the age of $2 \frac{1}{2}$ years bone radiographs remained normal. Weight and height were at the 75th and 90th centiles respectively, and the maximal tubular excretory capacity of phosphate had dropped to GFR $1.6 \mathrm{mg}$ $(0.53 \mathrm{mmol}) / 100 \mathrm{ml}$ filtrate.

\section{Discussion}

With the introduction of the active forms of vitamin D in the treatment of familial HR the outlook for these patients has improved substantially. ${ }^{12}$ The growth rate is accelerated, bone mineralisation becomes normal, and a better control of plasma parathyroid hormone is achieved as the secondary hyperparathyroidism frequently observed when other forms of vitamin D and phosphate are used does not occur. The treatment with phosphate alone has in some cases been successful, but with this regime hyperparathyroidism always develops. ${ }^{3}$ According to the published reports, $1 \alpha, 25\left(\mathrm{OH}_{2}\right)_{3}$ and phosphate combined is the most useful treatment for familial HR. Despite this, however, histologic normalisation of bone is not possible when rickets is already established. ${ }^{3-5}$

Moncrieff reported four children with familial HR studied since birth. He delayed treatment with $1 \alpha, 25\left(\mathrm{OH}_{2}\right)_{3}$ until bone lesions appeared but concluded that treatment should be started before radiographic bone lesions became apparent and that a raised alkaline phosphatase value and hypophosphataemia should be used as indicators. ${ }^{6}$

In our patient the treatment recommended by Moncrieff has prevented bone lesions. When we first saw this girl in 1979 we were concerned about the precise time to begin treatment and considered that the raised alkaline phosphatase value and hypophosphataemia were parameters valid enough to start active treatment for rickets. There have been no important problems associated with treatment and although we have no bone histology, we believe 
that in the long term and on the basis of the radiographic evidence our patient's bone structure may be normal.

\footnotetext{
References

1 Chan JCM, Bartter FC. Hypophosphatemic rickets: effect of 1,25-dihydroxyvitamin $\mathrm{D}_{3}$ on growth and mineral metabolism. Pediatrics 1979;64:488-95.

2 Chan JCM, Lovinger RD, Mamunes P. Renal hypophosphatemic rickets: growth acceleration after long-term treatment with 1,25-dihydroxyvitamin $\mathrm{D}_{3}$. Pediatrics $1980 ; 66: 445-54$.

3 Glorieux FH, Marie PJ, Pettifor JM, Delvin EE. Bone response to phosphate salts, ergocalciferol, and calcitriol in hypophosphatemic vitamin D-resistant rickets. $N$ Engl J Med 1980;303:1023-31.
}

4 Drezner MK, Lyles KW, Haussler MR, Harrelson JM. Evaluation of a role for 1,25-dihydroxyvitamin $\mathrm{D}_{3}$ in the pathogenesis and treatment of X-linked hypophosphatemic rickets and osteomalacia. J Clin Invest 1980; 66:1020-32.

5 Rasmussen H, Pechet M, Anast C, Mazur A, Gertner J, Broadus AE. Long-term treatment of familial hypophosphatemic rickets with oral phosphate and $1 \alpha$ hydroxyvitamin $\mathrm{D}_{3}$. J Pediatr $1981 ; 99: 16-25$.

6 Moncrieff MW. Early biochemical findings in familial hypophosphataemic, hyperphosphaturic rickets and response to treatment. Arch Dis Child 1982;57:70-2.

Correspondence to Dr M Roza, C/ Cervantes No 25, 40A, Oviedo, Spain.

Received 1 August 1983

\title{
Haemangioma with thrombocytopenia (Kasabach-Merritt syndrome)
}

\author{
T J DAVID, D I K EVANS, AND R F STEVENS \\ Department of Child Health, University of Manchester and Department of Haematology, Booth Hall \\ Children's Hospital, Manchester
}

SUMMARY We describe two patients with haemangioma with thrombocytopenia (Kasabach-Merritt syndrome). Both were treated with corticosteroids without notable improvement. The first patient responded satisfactorily to radiotherapy, whereas the second showed a slow spontaneous resolution.

Kasabach and Merritt ${ }^{1}$ first described the syndrome of thrombocytopenia with haemangioma. Approximately 100 cases have been reported subsequently. The haemangioma enlarges, usually in infancy, and at the same time there is a fall in the platelet count, together with hypofibrinogenaemia and a consumption coagulopathy. Radioisotope studies have shown an increased uptake within the haemangioma of platelets or fibrinogen, or of both. ${ }^{2}$ Surgery is not always possible. Radiotherapy, corticosteroids, anticoagulants, and antifibrinolytics have all been used, but none is clearly superior. We report two girls with haemangioma and thrombocytopenia in whom the use of corticosteroids was of little or no benefit.

\section{Case reports}

Case 1. The haemangioma presented at the age of $5 \frac{1}{2}$ weeks, and progressively enlarged. On admission at 7 weeks there was an extensive firm swelling below the chin extending into the neck on both sides but more on the right where it extended to the angle of the jaw (Figure). The haemangioma was also visible on the floor of the mouth below the tongue. The liver was palpable $3 \mathrm{~cm}$ below the costal margin. Investigations showed haemoglobin $8.5 \mathrm{~g} / \mathrm{dl}$, white cells $7 \cdot 9 \times 10^{9} / 1$, and platelets $20 \times 10^{9} / 1$. The blood film showed microcytosis, anisocytosis, burr cells, and a normal differential. The prothrombin time was 12.5 seconds (control 11.5 seconds), activated partial thromboplastin time 45 seconds (control 43 seconds), and fibrin degradation products between 10 and $40 \mu \mathrm{g} / \mathrm{ml}$ (normal less than $10 \mu \mathrm{g} / \mathrm{ml}$ ).

Treatment with epsilon aminocaproic acid and vitamin $\mathrm{K}$ was given for three weeks, followed by one week of prednisolone $4 \mathrm{mg} / \mathrm{kg} / \mathrm{day}$, but the haemangioma continued to enlarge rapidly and the platelet count fell to $9 \times 10^{9} / 1$. Surgical removal was impossible. Diminution in the size of the lesion occurred after a single dose of radiation (400 rads), but this was followed by enlargement of the lesion and haematological relapse. A second dose of 400 rads was followed by slow and complete regression of the lesion, so that the lesion had entirely disappeared by 14 months of age.

Case 2. A red swelling on the medial side of the left knee, presented at the age of 3 months, diagnosed initially as cellulitis and treated with penicillin. 